\title{
Variability in production of extracellular enzymes by different fungi isolated from rotten pear, peach and grape fruits
}

\section{Shazia Parveen ${ }^{1 *}$, Abdul Hamid Wani ${ }^{1}$, Mohd Yaqub Bhat ${ }^{1}$, Jahangir Abdullah Koka ${ }^{1}$ and Mohammad Afaan Fazili' ${ }^{12}$}

1Section of Mycology and Plant Pathology. Department of Botany. University of Kashmir. Hazaratbal, Srinagar, Jammu and Kashmir. India - 190006. *Email: shahshazia442@gmail.com.

${ }^{2}$ Genetics, Cytogenetics and Plant Breeding Laboratory. Department of Botany. Aligarh Muslim University. Aligarh - 202002. UP. India.

\begin{abstract}
Fifteen fungal pathogens, viz. Penicillium chrysogenum, Penicillium expansum, Monilinia fructigena, Trichothecium roseum, Cladosporium herbarum, Aspergillus niger, Coprinus psychromorbidus, Alternaria alternaria, Phytophthora palmivora, Pythium sp., Fusarium solani, Alternaria sp., Monilinia sp., Guignardia bidwellii and Rhizopus stolonifer isolated from rotted fruits were evaluted for the production of different enzyme on solid culture media. All the isolates produced enzymes on the media used, $87.67 \%$ of the isolated fungi were found to produce amylases, $80.00 \%$ of the fungi produced lipases, $73.33 \%$ produced proteases, cellulases by $66.67 \%$ and pectinases by $60.00 \%$. The array of enzymes produced differs between different fungi. Penicillium sp., Alternaria alternata, Rhizopus stolonifer and Alternaria sp. were found to produce all the tested enzymes on culture media. These pathogens are known to attack almost all the plants, fruits, vegetables and cause many diseases. The differences in the enzymatic production of different fungal pathogens represent their virulence and specificity in causing different fruit rot diseases.
\end{abstract}

Keywords: Culture media; Extracellular enzymes; Fungal pathogens; Peach; Pear; Grape.
Received

September 08, 2017

Accepted

December 06, 2017

Released

December 31, 2017

Open Access

Full Text Article

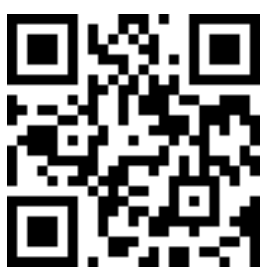

ORCIID

(1) 0000-0002-0086-2685 Shazia Parveen

(D) 0000-0002-6157-9656 Abdul Hamid Wani

(ㄱ) 0000-0002-0582-4813 Mohd Yaqub Bhat

(1) 0000-0003-0040-1624 Jahangir Abdullah Koka

(D) 0000-0003-4427-0806 Mohammad Afaan Fazili 


\section{Introduction}

Microorganisms are invaluable sources of natural products for industrial and biomedical development (Turner and Aldridge, 1983). They are common sources of commercial enzymes due to their high production capability, low cost, susceptibility to genetic manupilation, high biotechnological interest, pharmaceutical products and medical therapy (Rao et al., 1998). They are often more stable than enzymes derived from other sources (Sunitha et al., 2013). Fungi in general are well characterized microorganisms due to their capacity to produce different extracellular compounds; some of them are biologically very important causing severe reactions in other organisms (Mustafa and Kaur, 2009). These compounds include different types of enzymes and biologically active molecules. The microrganisms can represent a new source in obtaining enzymes with different potentialities. Enzyme cellulase and protease has wide applicability in various industrial processes like biofuel production, agricultural waste management, triphasic biomethanation and ligand binding studies (Chakraborty et al., 2000; Lu et al., 2004; Dias et al., 2008; Vaithanomsat et al., 2009). Most of the fungi produce enzymes which degrade the plant cell wall and hence result in pathogenesis. The degredative enzymes produced by different fungi are important in food deterioration, breakdown of organic matter and host infection.

Plant cell wall is complex structure of polymers, viz. Pectin, cellulose, hemicellulose, polysaccharides and lipids (Karr and Albersheim, 1970), for its degredation extracellular enzymes like pectinase, cellulase, protease, amylase, etc. are produced by different fungal pathogens and cause different diseases. Not much work seems to be reported on enzyme production by different pathogenic fungi causing rot of fruits. Experiments were therefore carried out to study the production of extracellular enzymes produced by different fungal pathogens for studing their virulance in causing rot of different fruits.

\section{Materials and methods}

\section{from fruits \\ Isolation of fungal pathogens}

Fifteen fungal pathogens, viz. Penicillium chrysogenum, Penicillium expansum, Monilinia fructigena, Trichothecium roseum, Cladosporium herbarum, Aspergillus niger, Coprinus psychromorbidus, Alternaria alternaria, Phytophthora palmivora, Pythium sp., Fusarium solani, Alternaria sp., Monilinia sp., Guignardia bidwellii and Rhizopus stolonifer were previously isolated from rotted pear, peach and grape fruits, stored on PDA medium at $4{ }^{\circ} \mathrm{C}$ in culture collection of Mycology and Plant Pathology Research Lab, Department of Botany, University of Kashmir and were screened for the production of different enzymes.

\section{by isolated fungi}

\section{Detection of enzymes produced}

The production of following enzymes was detected: Amylase, Cellulase, Pectinase, Protease and Lipase. For determining the enzymatic activity the rot causing fungal pathogens were inoculated on the specific culture media for each enzyme to be investigated. These were incubated at $28 \pm 2{ }^{\circ} \mathrm{C}$ and the enzymatic index was determined after $96 \mathrm{~h}$. Enzyme activity index or enzymatic Index (EI) was expressed by the relationship between average diameter of the degradation halo and average diameter of the colony (Hankin et al., 1971; Hankin and Anagnostakis, 1975)

\section{activity \\ Determination of amylolytic}

The ability to degrade starch by the fungal pathogens is an essential criterion to determine amylolytic activity. The medium used was nutrient agar supplemented with $0.2 \%$ soluble starch at $\mathrm{pH} 6$ (Hankin and Anagnostakis, 1975). After $96 \mathrm{~h}$ of incubation the plates were flooded with iodine solution which visualized the clear halos around the fungal colonies. 

activity

\section{Determination of Cellulolytic}

The methodology given by Teather and Wood (1982) was used to determine cellulase activity. Medium used was Czapek Dox Agar medium containing sucrose (30 g), $\mathrm{NaNO}_{3}(2 \mathrm{~g}), \mathrm{K}_{2} \mathrm{HPO}_{4}(1 \mathrm{~g})$, $\mathrm{MgSO}_{4}$ (0.05 g), KCl (0.5 g), $\mathrm{FeSO}_{4}(0.01$ g) and Agar (20 g) supplemented with $1 \%$ carboxy methyl cellulose. After $96 \mathrm{~h}$ (4 days) of incubation the plates were flooded with $0.2 \%$ aqueous congo red solution and destained with1M $\mathrm{NaCl}$ solution for $15 \mathrm{~min}$. The presence of yellow areas around fungal colony indicates the presence of cellulase activity.

\section{activity}

Determination of pectinolytic

Methodology given by Hankin et al. (1971) was used to determine pectinolytic activity. Medium used was pectin agar medium containing yeast extract (1 g), Agar (15 g), pectin (5 g) in 1,000 mL distilled water at $\mathrm{pH} 5$. After $96 \mathrm{~h}$ of incubation the culture plates were flooded by $1 \%$ aqueous solution of hexadecyl trimethyl ammonium bromide. It precipitates intact pectin in the medium and thus clear zones around the colony indicated pectinase activity by the fungi.

\section{activity}

Determination of proteolytic

Medium used was Frazier's gelatin agar, containing nutrient agar and $0.4 \%$ gelatin (4 g.L $\mathrm{L}^{-1}$ ). After incubation at $30{ }^{\circ} \mathrm{C}$ for $96 \mathrm{~h}$ the complete degradation of gelatin was seen around the colonies. The plates were treated with ammonium sulphate that enhance clear zones around the colonies.

\section{avtivity}

Determination of lipolytic

To detect the lipolytic activity medium described by Sierra (1957) was used. The medium contains peptone $(10 \mathrm{~g})$, $\mathrm{NaCl}$ (5 g), $\mathrm{CaCl} 2 \mathrm{H}_{2} \mathrm{O}$ (0.1 g), agar (20 g) at $\mathrm{pH}$ 6, tween 20 was sterilized separately and added $1 \mathrm{~mL}$ per $100 \mathrm{~mL}$ of the medium that serves as lipid source. After incubation for $96 \mathrm{~h}$ the presence of halos were observed.

\section{Results}

In the present study enzymatic index of the fifteen isolated fungal pathogens, viz. Penicillium chrysogenum, Penicillium expansum, Monilinia fructigena, Trichothecium roseum, Cladosporium herbarum, Aspergillus niger, Coprinus psychromorbidus, Alternaria alternaria, Phytophthora palmivora, Pythium sp., Fusarium solani, Alternaria sp., Monilinia sp., Guignardia bidwellii and Rhizopus stolonifer is given in Table 1 .

It was revealed from the results that P. chrysogenum, A. alternata, $R$. stolonifer and Alternaria sp. were found to produce all the tested enzymes in culture media. Among the isolated fungi, $86.67 \%$ of the isolated fungi were found to produce amylases, $80.00 \%$ of the fungi produced lipases, $73.33 \%$ produced proteases, cellulases by $66.67 \%$ and pectinases by $60.00 \%$ (Figure 1, Table 1).

All the fungi produced extracellular enzymes on the solid culture media which is interpreted by clear zones around microbial colonies. The term enzyme production here refers to synthesis of the enzyme by the fungus as well as its activity in the medium after it is produced. Maximum cellulase activity was found in T. roseum followed by P. expansum, A. alternata, F. solani, Alternaria sp. and $P$. chrysogenum than rest of the fungal pathogens. Cellulase activity was found absent in $M$. fructigena, C. herbarum, A. niger, Monilinia sp. and G. bidwellii. Maximum amylase activity was observed in A.niger, followed by T.roseum, P. expansum, Monilinia sp. and P. palmivora while C. herbarum and F. solani doesn't show any amylase activity.

Maximum pectinase activity was observed in $A$. niger followed by $C$. herbarum, M. fructigena, Alternaria sp. and $F$. solani. Pectinases were found absent in $T$. roseum, $C$. psychromorbidus, $P$. palmivora, Pythium sp. and Monilinia sp. Protease activity was reported maximum in C. herbarum, A. niger, P. chrysogenum, T. roseum, C. psychrmorbidus and Monilinia sp. Lipase activity was observed 
maximum in $A$. niger, $T$. roseum, $P$. palmivora, P. expansum, Monilinia sp., Alternaria sp. and $P$. chrysogenum. Enzyme Protease was found absent in $P$. expansum, P. palmivora, Pythium sp. and $G$. bidwellii likewise enzyme lipase was absent in M. fructigena, Cladosporium sp. and C. psychromorbidus.

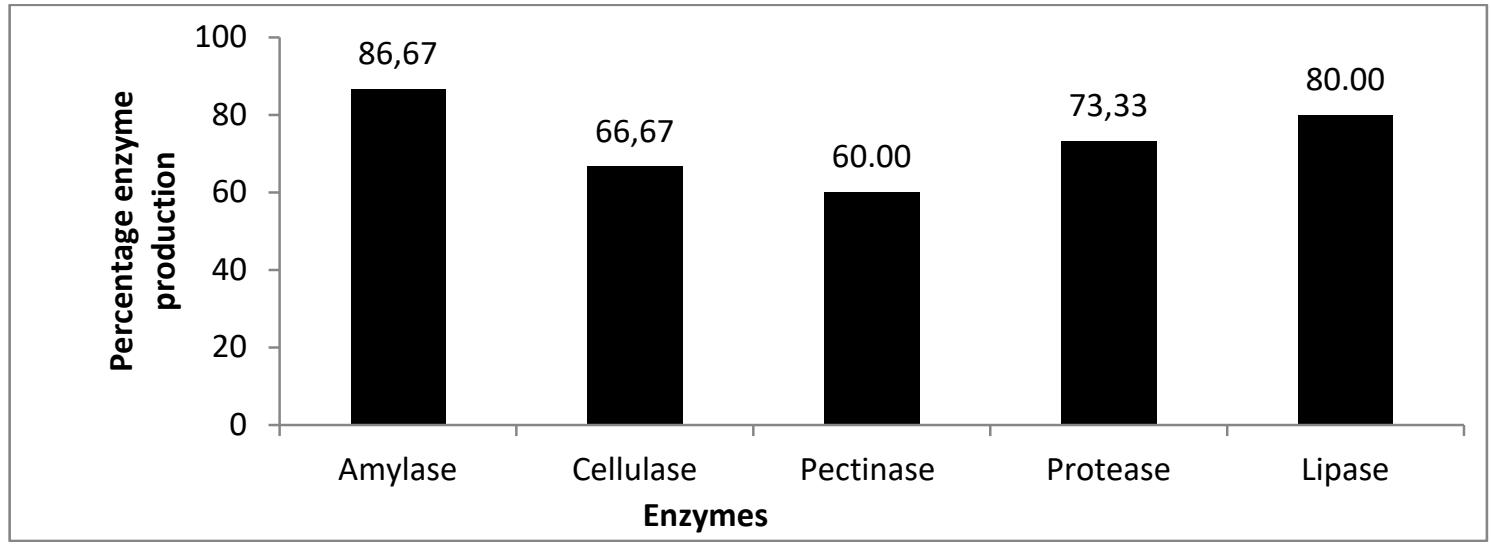

Figure 1. Percentage of isolated fungi showing different enzyme production on solid culture media.

Table 1. Enzymatic index of different rot fungi isolated from fruits.

\begin{tabular}{lccccc}
\hline \multirow{2}{*}{ Fungal pathogen } & \multicolumn{5}{c}{ Enzymatic Index (EI) } \\
\cline { 2 - 6 } & Amylase & Cellulase & Pectinase & Protease & Lipase \\
\hline Penicillium chrysogenum & 1.26 & 1.33 & 1.34 & 1.68 & 1.39 \\
Penicillium expansum & 1.62 & 1.82 & 0.00 & 0.00 & 1.79 \\
Monilinia fructigena & 1.47 & 0.00 & 1.88 & 1.28 & 0.00 \\
Trichothecium roseum & 1.95 & 2.03 & 0.00 & 1.65 & 2.17 \\
Cladosporium herbarum & 0.00 & 0.00 & 1.96 & 3.06 & 0.00 \\
Aspergillus niger & 3.70 & 0.00 & 2.56 & 2.38 & 2.42 \\
Coprinus psychromorbidus & 1.36 & 1.27 & 0.00 & 1.63 & 0.00 \\
Alternaria alternaria & 1.31 & 1.43 & 1.16 & 1.41 & 1.28 \\
Phytophthora palmivora & 1.51 & 1.28 & 0.00 & 0.00 & 2.08 \\
Pythium sp. & 1.13 & 1.30 & 0.00 & 0.00 & 1.31 \\
Fusarium solani & 0.00 & 1.40 & 1.45 & 1.29 & 1.26 \\
Alternaria sp. & 1.22 & 1.35 & 1.74 & 1.29 & 1.42 \\
Monilinia sp. & 1.62 & 0.00 & 0.00 & 1.52 & 1.59 \\
Guignardia bidwellii & 1.20 & 0.00 & 1.24 & 0.00 & 1.11 \\
Rhizopus stolonifer & 1.28 & 1.22 & 1.45 & 1.23 & 1.17 \\
\hline
\end{tabular}

\section{Discussion}

It was revealed during the present study that all the fungi produced extracellular enzymes on the solid culture media. The array of enzymes produced differs between different fungi. $P$. chrysogenum, A. alternata, $R$. stolonifer and Alternaria sp. were found to produce all the tested enzymes, viz. amylase, cellulase, pectinase, protease and lipase on culture media. The differences in the enzymatic production of different fungal pathogens represent their virulence and specificity in causing fruit rot diseases. Plant cell wall is complex structure of 
polymers, viz. Pectin, cellulose, hemicellulose, polysaccharides and lipids (Karr and Albersheim, 1970), is degraded by the enzymes like pectinase, cellulase, protease, amylase and lipase produced by different virulent plant pathogens (fungal as well as bacterial). These enzymes change the chemistry of cell wall and cause its degradation (Albersheim et al., 1969). Microbial pectinases are important enzymes involved in phytopathologic process and in decomposition of plant dead material. Degredation of the host tissue begins with the production of pectinolytic enzymes which are main enzymes involved in plant attack (Hoondal et al., 2002). Extracellular proteases secreated by fungi espacially yeasts have been investigated for industrial use due to organisms fast growth and ability to grow under adverse conditions (Poza et al., 2001). Pectinase and cellulases produced by the rot causing fungal pathogens are essential enzymes in initiating the process of degradation of cell wall (Ahmad et al., 2006) further spread of the pathogen is caused by the enzyme protease and lipase, which are important enzymes in pathogenesis (Hameed et al., 1994). The variation in the enzyme production by different rot fungi suggests there specificity for the rot causing capability and pathogenesis.

Sunitha et al. (2013) reported that cellulases, amylases and pectinases are major enzymes involved in plant polysaccharide degradation along with protease. The production of extracellular cellulase and pectinase by the fungal pathogens indicates that the fungus is well equipped for penetration, decomposition of the host cells (Sieber-Canavesi et al., 1991). Ahmad et al. (2006) reported the enzymatic activities, viz. pectinase, cellulase, protease and lipase of fungal pathogens isolated from corn stalk rot disease and reported that the enzyme production differs for different pathogens and depends on the virulence and specificity of the pathogen in causing the disease.

\section{Conflict of interests}

The authors declare that there are no conflicts of interest.

\section{References}

Ahmad, Y.; Hameed, A.; Ghaffar, A. Enzymatic activity of fungal pathogens in corn. Pakistan Journal of Botany, v. 38, p. 1305-1316, 2006. Available from: <http://www.pakbs.org/pjbot/ PDFs/38(4)/PJB38(4)1305.pdf $>$. Accessed on: Apr. 23, 2017.

Albersheim, P.; Jones, T. M.; English, P. D. Biochemistry of cell wall in relation to infective process. Annual Review Phytopathology, v. 7, p. 171-194, 1969. https://doi.org/10.1146/ annurev.py.07.090169.001131

Chakraborty, N.; Sarkar, G.M.; Lahiri, S. C. Cellulose degrading capabilities of cellulolytic bacteria isolated from the intestinal fluids of the silver cricket. Environmentalist, v. 20, no. 1, p. 9-11, 2000. https://doi.org/10.1023/A: 1006691524607

Dias, D. R.; Vilela, D. M.; Silvestre, M. P. C.; Schwn, R. F. Alkaline proteases from Bacillus sp. isolated from coffee bean grown on cheese whey. World Journal of Microbiology and Biotechnology, v. 24, p. 2027-2034, 2008. https://doi.org/10.1007/s11274-008-9706-6

Hameed, A.; Natt, M. A.; Iqbal, M. J. The role of protease and lipase in plant pathogenesis. Pakistan Journal of Phytopathology, v. 6, p. 13-16, 1994.

Hankin, L.; Anagnostakis, S. L. The use of solid media for detection of enzyme production by fungi. Mycologia, v. 67, p. 597-607, 1975. https://doi.org/10.2307/3758395

Hankin, L.; Zucker, M.; Sands, D. C. Improved solid medium for the detection and enumeration of pectolytic bacteria. Applied Microbiology, v. 22, p. 205-209, 1971. Available from: $<$ https://www.ncbi.nlm.nih.gov/pmc/articles/PM C377414/pdf/applmicro00118-0075.pdf>.

Accessed on: Apr. 23, 2017.

Hoondal, G. S.; Tiwari, R. P.; Tewari, R.; Dahiya, N.; Beg, Q. K. Microbial alkaline pectinases and their industrial applications: a review. Applied Microbiology and Biotechnology, v. 59, no. 3/4, p. 409-418, 2002. https://doi.org/10.1007/s00253-002-1061-1 
Karr, A. L.; Albersheim, P. Polysaccharide degrading enzymes are unable to attack plant cell walls without prior action by cell wall modifying enzyme. Plant Physiology, v. 46, p. 69-80, 1970. https://doi.org/10.1104/ pp.46.1.69

Lu, W.-J.; Wang, H.-T.; Nie, Y.-F.; Wang, Z.C.; Huang, D.-Y.; Qiu, X.Y.; Chen, J.-C. Effect of inoculating flower stalks and vegetables waste with ligno-cellulolytic microorganism on the composting process. Journal of Environmental Science and Health, Part B, v. 39, no. 5/6, p. 871-887, 2004.

Mustafa, U.; Kaur, G. Extracellular enzyme production in Metarhizium anisopliae isolates. Folia Microbiologica, v. 54, p. 499-504, 2009. https://doi.org/10.1007/s12223-009-0071-0

Poza, M.; Miguel, T.; Siero, C.; Vill, T. G. Characterization of a broad $\mathrm{pH}$ range protease of Candida caseinolytica. Journal of Applied Microbiology, v. 91, p. 916-921, 2001. https://doi.org/10.1046/j.1365-2672.2001. 01458.x

Rao, M. B.; Tanksale, A. M.; Ghatge, M. S.; Deshpand, V. V. Molecular and biotechnological aspects of microbial proteases. Microbiology and Molecular Biology Reviews, v. 62, no. 3, p. 597-635, 1998. Available from: <http://mmbr.asm.org/ content/62/3/597.full.pdf $>$. Accessed on: Apr. 24, 2017.

Sieber-Canavesi, F.; Petrini, O.; Sieber, T. N. Endphytic Leptostroma species on Picea abies, Abies alba and Abies balsamea: a cultural, biochemical and numerical study. Mycologia, v. 83, no. 1, p. 89-90, 1991. https://doi.org/ $10.2307 / 3759835$
Sierra, G. A simple method for the detection of lipolytic activity of micro-organisms and some observations on the influence of the contact between cells and fatty substrates. Antonie van Lecuwenhock, v. 23, no. 1, p. 15-22, 1957. https://doi.org/10.1007/BF02545855

Sunitha, V. H.; Devi, D. N.; Srinivas, C. Extracellular enzymatic activity of endophytic fungal strains isolated from medicinal plants. World Journal of Agricultural Sciences, v. 9, p. 1-9, 2013. https://doi.org/10.5829/ idosi.wjas.2013.9.1.72148

Teather, R. M.; Wood, P. J. Use of Congo red polysaccharide interactions in enumeration and characterization of cellulolytic bacteria from the bovine rumen. Applied and Environmental Microbiology, v. 43, p. 777-780, 1982. Available from: <https://www.ncbi.nlm.nih.gov/ pmc/articles/PMC241917/pdf/aem001850051.pdf >. Accessed on: Apr. 24, 2017.

Turner, W. B.; Aldridge, D. C. Fungal Metabolites London: Academic Press, 1983. v. 2.

Vaithanomsat, P.; Chuichucherm, S.; Apiwatanapiwat, W. Bioethanol production from enzymatically saccharified sunflower stalks using steam explosion as pretreatment. Proceeding of World Academy of Science, Engineering and Technology, v. 37, p. 140143, 2009. Available from: $<$ https://waset.org/publications/1318/bioethanol -production-from-enzymatically-saccharifiedsunflower-stalks-using-steam-explosion-aspretreatment>. Accessed on: Apr. 24, 2017. 